\title{
Chitosan Oligomers and Copper Sulfate Induce Grapevine Defense Reactions and Resistance to Gray Mold and Downy Mildew
}

\author{
Aziz Aziz, Patricia Trotel-Aziz, Laurent Dhuicq, Philippe Jeandet, Michel Couderchet, and Guy Vernet
}

First, second, fifth, and sixth authors: Eco-Toxicologie, URVVC-EA 2069, Université de Reims, B.P. 1039, F-51687 Reims cedex 2, France; third author: Agrolor, CA Le Cahn 17, rue Laurent Bonnevay 54100 Nancy, France; and fourth author: Enologie \& Chimie Appliquée, URVVC-EA 2069, Université de Reims, B.P. 1039, F-51687 Reims cedex 2, France.

Current address of A. Aziz, P. Trotel-Aziz, and M. Couderchet: Plantes-Pesticides \& Développement Durable, URVVC-EA 2069, Université de Reims, B.P. 1039, F-51687 Reims cedex 2, France.

Accepted for publication 22 May 2006.

\section{ABSTRACT}

Aziz, A., Trotel-Aziz, P., Dhuicq, L., Jeandet, P., Couderchet, M., and Vernet, G. 2006. Chitosan oligomers and copper sulfate induce grapevine defense reactions and resistance to gray mold and downy mildew. Phytopathology 96:1188-1194.

Chitosan (CHN), a deacetylated derivative of chitin, was shown to be efficient in promoting plant defense reactions. CHN oligomers of different molecular weight (MW) and degree of acetylation (DA) triggered an accumulation of phytoalexins, trans- and cis-resveratrol and their derivatives $\varepsilon$-viniferin and piceid, in grapevine leaves. Highest phytoalexin production was achieved within $48 \mathrm{~h}$ of incubation with CHN at $200 \mu \mathrm{g} / \mathrm{ml}$ with an MW of 1,500 and a DA of 20\% (CHN1.5/20), while oligomers with greater MW were less efficient, indicating that a specific MW threshold could be required for phytoalexin response. Treatment of grapevine leaves by highly active CHN1.5/20 also led to marked induction of chitinase and $\beta$-1,3-glucanase activities. CHN1.5/20 applied together with copper sulfate $\left(\mathrm{CuSO}_{4}\right)$ strongly induced phytoalexin accumulation. $\mathrm{CuSO}_{4}$ alone, especially at low concentrations also elicited a substantial production of phytoalexins in grapevine leaves. Evidence is also provided that CHN1.5/20 significantly reduced the infection of grapevine leaves by Botrytis cinerea and Plasmopara viticola, and in combination with $\mathrm{CuSO}_{4}$ conferred protection against both pathogens.

Additional keywords: elicitor, Vitis vinifera.
Plants can express defense mechanisms that provide protection against various pathogenic microorganisms. Successful protection depends on the timely recognition of signals or elicitor molecules generated or released during pathogen attack and the rapid induction of appropriate plant defense reactions $(24,34)$. These defense responses include production of reactive oxygen species, phytoalexin biosynthesis, reinforcement of plant cell walls, and the accumulation of pathogenesis-related (PR) proteins, some of which possess antimicrobial properties $(5,29,46,50)$. Similar defense responses can also occur upon treatment of plants with elicitor molecules before contact with the pathogen $(7,9,28$, $36,38,47)$.

Various types of elicitors have been reported in the literature, including oligosaccharides derived from the cell wall of various fungi, bacteria, and host plants $(6,11,16,19,24,31)$, or from marine algae $(7,31,36,38)$. In recent years, the importance of chitosaccharides as plant growth promoting and disease control agents has been emphasized $(3,4,49,51)$. Chitosan $(\mathrm{CHN})$, a beta-1,4-linked glucosamine, is a totally or partially deacetylated derivative of chitin (26). It has been shown to elicit a variety of defense reactions in higher plants such as the stimulation of phenylalanine ammonia lyase (PAL), peroxidase, and lipoxygenase activities, as well as the accumulation of phytoalexins and PR proteins (3, $15,22,27,31,49)$. CHN oligomers are also active elicitors of lignification in wounded and intact wheat leaves $(8,51)$. Their biological activity was thought to result from their binding to membrane receptors (20) and to depend on the molecular weight (MW) and degree of $N$-acetylation of the molecule (DA) $(35,51)$.

Corresponding author: A. Aziz; E-mail address: aziz.aziz@univ-reims.fr

DOI: $10.1094 /$ PHYTO-96-1188

(C) 2006 The American Phytopathological Society
In melon plants, $\mathrm{CHN}$ oligomers with a DA over $10 \%$ were shown to stimulate chitinase activity (45), and with a DA of less than $20 \%$ they also acted as an elicitor of PAL activity in wheat leaves (51). CHN oligomers of low MW were shown to be more effective in inducing defense responses than those of higher MW. Furthermore, some CHNs have been reported to enhance systemic resistance against pathogenic fungi in tomato (9) and rice seedlings (3).

Gray mold, caused by the fungus Botrytis cinerea, and downy mildew, caused by Plasmopara viticola, are among the most damaging diseases of grapevine (Vitis vinifera L.). Control of these pathogens is generally achieved with chemical fungicide and copper salt applications. However, the appearance of fungicide-resistant pathogen strains and negative environmental impacts associated with these practices has intensified the need for reducing chemical use and for alternative disease management methods. In grapevine, the most thoroughly characterized inducible defense reactions by pathogenic fungi are the accumulation of phytoalexins and the synthesis of PR proteins including chitinases and $\beta$-1,3-glucanases $(10,13,17,21,33)$. The main phytoalexins, trans-resveratrol and viniferin, are considered to be fungitoxic at physiological concentrations against $B$. cinerea (2) and can enhance grapevine plant resistance against $P$. viticola $(18,41)$. Similar responses have also been activated by inducers of systemic acquired resistance, wounding, aluminum chloride, jasmonates, and UV irradiation $(12,13,48)$. Recently, Hamiduzzaman et al. (28) reported that $\beta$-aminobutyric acid also potentiated expression of PR protein genes and induced resistance of grapevine plants against $P$. viticola. Similarly, algal $\beta-1,3$-glucan laminarin and oligogalacturonides elicited a variety of defense responses in grapevine cell suspension cultures and leaves, including accumulation of phytoalexins and activation of a set of PR genes and proteins $(6,7)$. In addition, the pretreatment of grapevine leaves or 
plants by these oligosaccharides conferred significant resistance against $B$. cinerea and $P$. viticola.

This study was undertaken to determine whether treatment of grapevine leaves with water-soluble $\mathrm{CHN}$ oligomers induces resistance to $B$. cinerea and $P$. viticola. For this purpose, the elicitor activity of CHN oligomers with a wide range of known MW and DA was investigated through phytoalexin accumulation in grapevine leaves. We further examined the ability of the most active $\mathrm{CHN}$ to induce chitinase and $\beta$-1,3-glucanase activities, and to protect grapevine leaves against $B$. cinerea and $P$. viticola. In addition, the combination of this $\mathrm{CHN}$ oligomer with $\mathrm{CuSO}_{4}$ at low concentrations in inducing phytoalexin accumulation and resistance of grapevine leaves against both pathogens was also investigated.

\section{MATERIALS AND METHODS}

Biological materials. Grapevine plantlets (Vitis vinifera cv. Chardonnay 7535) were obtained by multiplication in vitro on modified Murashige and Skoog (40) medium, pH 5.9 (half concentration of macroelements and glutamine at $200 \mathrm{mg} / \mathrm{liter}$ ), supplemented with sucrose ( $20 \mathrm{~g} /$ liter $)$ and agar ( $7 \mathrm{~g} / \mathrm{liter})$. Plantlets were grown at $25^{\circ} \mathrm{C}$ with a photoperiod of $16 \mathrm{~h}$ of light. Grapevine plants were obtained from cuttings cultivated in the greenhouse $\left(24\right.$ to $\left.28^{\circ} \mathrm{C}\right)$.

B. cinerea strain 630 (obtained from Y. Brygoo, INRA, Versailles, France) was grown on potato dextrose agar at $22^{\circ} \mathrm{C}$. $P$. viticola-infected leaves were harvested in a Champagne vineyard (France) and sporangia were washed from infected leaves by brushing them into sterile distilled water. They were either used freshly or stored in a sterile solution containing $10 \%$ glycerol at $-80^{\circ} \mathrm{C}$.

Chemicals. Crab-shell CHN oligomers with an MW of 1,500 to 10,000 and DA from 2 to $30 \%$ were obtained from Agrolor (Nancy, France). They were prepared according to the method of Domard and Cartier (23). Copper sulfate was purchased from Sigma (St. Louis, MO).

Treatments. Leaves were excised from 10-week-old grapevine in vitro grown-plantlets (cv. Chardonnay) and incubated by floating them on a reference buffer (2 mM MES, pH 5.9, containing $0.5 \mathrm{mM} \mathrm{CaCl}_{2}$ and $0.5 \mathrm{mM} \mathrm{K}_{2} \mathrm{SO}_{4}$ ). The elicitation process was carried out with $\mathrm{CHN}$ fragments differing in their MW and DA at concentrations of $\leq 300 \mu \mathrm{g} / \mathrm{ml}$. CHN was also used in combination with $\mathrm{CuSO}_{4}$ at concentrations ranging from 1 to $100 \mu \mathrm{g} / \mathrm{ml}$. Both $\mathrm{CHN}$ and copper sulfate were dissolved in the reference buffer adjusted to $\mathrm{pH}$ 5.9.

Phytoalexin quantification. Grapevine leaves were collected at different times after treatment and ground in liquid nitrogen with a chilled mortar and pestle, and $4 \mathrm{ml}$ of $95 \%$ methanol was added to $1 \mathrm{~g}$ of the obtained powder. All extraction steps were done in subdued light conditions. After centrifugation $(10 \mathrm{~min}$, $5,000 \times g$ ), supernatants were evaporated under nitrogen and phytoalexins were solubilized by addition of $1 \mathrm{ml}$ of $100 \%$ methanol. This solution was clarified by filtration through a Millex-GN $0.22-\mu \mathrm{m}$ filter (Millipore, St-Quentin en y, France) before highperformance liquid chromatography analysis. Twenty microliters of each sample was loaded onto a Lichrocart C-18 reversed phase column (250 mm $\times 4 \mathrm{~mm}, 5 \mu \mathrm{m}$, Waters, St-Quentin en y, France) equilibrated with a 90:10 (vol/vol) $\mathrm{H}_{2} \mathrm{O}$ /acetonitrile mobile phase. Phytoalexins were eluted with a linear gradient of 10 to $85 \%$ acetonitrile at a flow rate of $1 \mathrm{ml} / \mathrm{min}$. Trans- and cis-phytoalexins were detected with a photodiode array detector coupled to a fluorometer detector $(\lambda \mathrm{ex}=330 \mathrm{~nm}, \lambda \mathrm{em}=374 \mathrm{~nm})$ and quantified on the basis of a standard calibration curve of trans-resveratrol, as previously described $(32,43)$.

Chitinase and $\boldsymbol{\beta}-\mathbf{1 , 3}$-glucanase activity assays. Enzymes were extracted by grinding $250 \mathrm{mg}$ of fresh leaves in $2 \mathrm{ml}$ of $50 \mathrm{mM}$ sodium acetate buffer, $\mathrm{pH} 5$, containing $1 \mathrm{mM}$ dithiothreitol and
$0.2 \%$ (wt/vol) phenylmethylsulfonyl fluoride. Homogenates were centrifuged at $9,000 \times g$ for $10 \mathrm{~min}$ at $4^{\circ} \mathrm{C}$ and supernatants were used for enzymatic activity assays. Chitinase and $\beta$-1,3-glucanase activities were assayed according to the method of Wirth and Wolf (52) using carboxymethyl-chitin-Remazol-Brilliant Violet (CM-chitin-RBV) and carboxymethyl-curdlan-Remazol-Brilliant Blue (CM-curdlan-RBB) as respective substrates (Loewe Biochemica, Germany).

Protection assays. For $B$. cinerea infections, conidia were collected with $10 \mathrm{ml}$ of sterile water from a 10-day-old potato dextrose agar culture, filtered to remove mycelia, and counted. For each treatment, 30 leaves were excised from 10-week-old grapevine in vitro-grown plantlets and pre-incubated by floating them on a standard buffer $\left(2 \mathrm{mM}\right.$ MES, $0.5 \mathrm{mM} \mathrm{CaCl}_{2}$, and $0.5 \mathrm{mM} \mathrm{K}_{2} \mathrm{SO}_{4}, \mathrm{pH} 5.9$ ) containing various concentrations of $\mathrm{CHN}(\mathrm{CHN} 1.5 / 20)$ and/or $\mathrm{CuSO}_{4}$ at defined concentrations. After $48 \mathrm{~h}$, leaves were rinsed with distilled water and placed on wet absorbing paper in plastic petri dishes. One needle-prick wound was applied to the abaxial surface of each leaf, and the fresh wounds were covered with 5 - $\mu$ l drops of a suspension of $5 \times$ $10^{5}$ conidia per $\mathrm{ml}$. Quantification of disease development was measured as the average diameter of lesions formed 6 days postinoculation.

For $P$. viticola infections, cuttings with seven to eight expanded leaves were first sprayed on both leaf surfaces with solutions of $\mathrm{CHN} 1.5 / 20$ at $200 \mu \mathrm{g} / \mathrm{ml}$ with or without $\mathrm{CuSO}_{4}$ at $50 \mu \mathrm{g} / \mathrm{ml}$. Plants were placed in a growth chamber $\left(25^{\circ} \mathrm{C}, 16 \mathrm{~h}\right.$ of daylight, $70 \%$ relative humidity) for 8 days, and then the abaxial surface of detached leaves was inoculated by application of $20-\mu$ drops of a suspension of $5 \times 10^{4}$ sporangia per $\mathrm{ml}$. Inoculated leaves were placed in glass covered dishes, incubated for $16 \mathrm{~h}$ in the dark, and then placed in a growth chamber under the conditions described above. Disease was estimated 8 days postinoculation by measuring the percentage of leaf area covered with mycelia. Analysis of variance and Duncan's multiple range test were performed for all assays.

\section{RESULTS}

Time course of phytoalexin production in response to $\mathrm{CHN}$. Resveratrol (trans-3,4',5-trihydroxystilbene) and its dehydrodimer $\varepsilon$-viniferin have been reported as the major phytoalexins produced by grapes (Vitis spp.) in response to microbial infection and associated with resistance to fungal pathogens $(2,17,33,42)$. Here grapevine leaves were challenged by two CHNs $(200 \mu \mathrm{g} / \mathrm{ml})$ differing in MW and DA; CHN1.5/20 with MW of 1,500 and a DA of $20 \%$, and CHN10/2 with MW of 10,000 and a DA of $2 \%$. As shown in Figure 1, induction of resveratrol and derivatives, trans- and cis-viniferin and piceid, was observed following treatment of grapevine leaves with CHNs. The accumulation of transresveratrol (Fig. 1A) increased more rapidly than its cis isomer (Fig. 1B) and their metabolites, trans- and cis- $\varepsilon$-viniferin (Fig. 1C and D) and piceid (Fig. 1A and F). For both CHNs, the production of phytoalexins showed similar profiles with maximum accumulation of resveratrol and $\varepsilon$-viniferin at 48 -h postelicitation. Thereafter, trans-resveratrol accumulation declined slightly, while $\varepsilon$ viniferin and piceid accumulation remained stable until $72 \mathrm{~h}$. Amounts of phytoalexins were generally greater with CHN1.5/20 (by two- to threefold) than with CHN10/2, suggesting that phytoalexin response could be dependent on either the MW or the DA of CHN.

Effects of MW and DA of CHN on phytoalexin production. In order to investigate whether MW and DA of CHN can influence phytoalexin accumulation in grapevine, leaves were treated for $48 \mathrm{~h}$ with different $\mathrm{CHN}$ of $1.5,5$, and $10 \mathrm{kDa}$ and DA ranging from 2 to $30 \%$ at a concentration of $200 \mu \mathrm{g} / \mathrm{ml}$. The accumulation of all elicited phytoalexins was directly dependent upon the MW of the CHN backbone (Fig. 2). The trans isomers remained pre- 
dominant and were more influenced by the CHN structure than cis isomeric forms. The pattern of the resveratrol response (Fig. 2A) was similar to that of $\varepsilon$-viniferin (Fig. 2B) and piceid (Fig. $2 \mathrm{C}$ ) in that, in all cases, the larger CHNs (10 kDa) were less active. The CHN with low molecular mass ( 1.5 to $3 \mathrm{kDa})$ induced the largest accumulation of all phytoalexins. The DA appeared to influence the elicitor activity of $\mathrm{CHN}$. Phytoalexin production increased with decreasing DA, with some dependency on MW. The highest phytoalexin accumulation was obtained with a DA of 2 to $20 \%$ for $\mathrm{CHN}$ of 1.5 and $3 \mathrm{kDa}$. For both $\mathrm{MW}$, the maximum production of resveratrol and $\varepsilon$-viniferin was observed with a DA of $20 \%$. Maximum piceid levels (Fig. 2C) were also obtained with CHN of low MW and a DA of $20 \%$, indicating that both MW and DA can modulate $\mathrm{CHN}$ elicitor activity.

Dose-response curves for phytoalexin production by CHN1.5/20. When grapevine leaves were incubated in the presence of CHN1.5/20 for $48 \mathrm{~h}$, the production of trans- and cisresveratrol and piceid (Fig. 3A) increased with increasing concentrations of CHN. $\varepsilon$-Viniferin (Fig. 3B) also accumulated under its trans form together with a small amount of the cis isomer. The accumulation of major phytoalexins did not increase with treatments of CHN greater than $200 \mu \mathrm{g} / \mathrm{ml}$ (Fig. 3), while cis- $\varepsilon$-viniferin content significantly increased at $\mathrm{CHN}$ concentrations higher than $200 \mu \mathrm{g} / \mathrm{ml}$.

Chitinase and $\beta-1,3$-glucanase activities in response to CHN1.5/20. Chitinase and $\beta$-1,3-glucanase are PR proteins that are considered to have antimicrobial activity against different pathogens. In grapevine leaves, the most active $\mathrm{CHN}$ in terms of phytoalexin production induced chitinase and $\beta$-1,3-glucanase activities (Fig. 4) with similar trends; both enzyme activities were increased at $10 \mathrm{~h}$ after $\mathrm{CHN}$ treatment with maximum accumulation at $24 \mathrm{~h}$, and activity remained high for at least $48 \mathrm{~h}$. Dose-
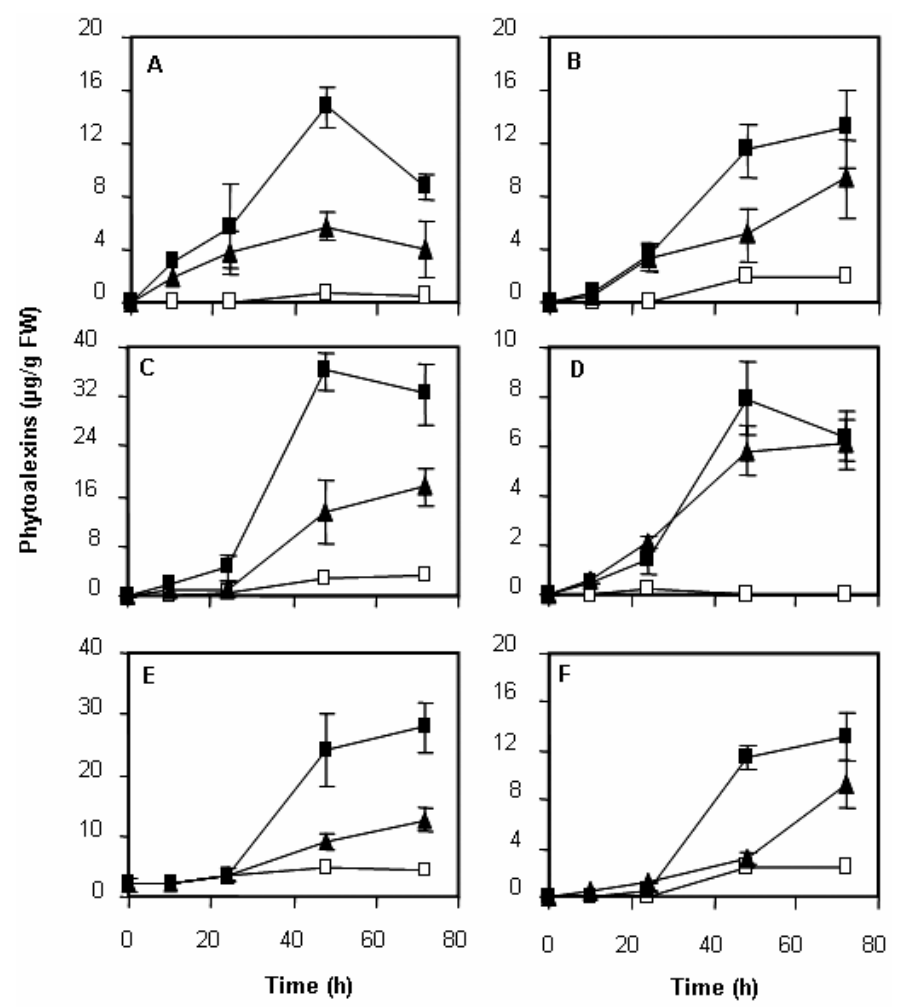

Fig. 1. Time-response curves of phytoalexin elicitation in grapevine leaves by chitosan $(200 \mu \mathrm{g} / \mathrm{ml})$ of different molecular weight and degree of acetylation (DA). CHN1.5/20, $1.5 \mathrm{kDa}$ and DA 20\% (solid square); CHN10/2, $10 \mathrm{kDa}$ and DA $2 \%$ (solid triangle); and buffer control (open square). Data are means \pm standard deviation from three independent experiments. A, trans-resveratrol;

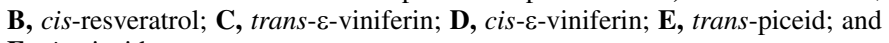
F, cis-piceid. response experiments showed that both PR enzymes are clearly stimulated by a CHN concentration of $100 \mu \mathrm{g} / \mathrm{ml}$. Maximal induction of chitinase and $\beta$-1,3-glucanase activities was obtained with a concentration of 200 to $300 \mu \mathrm{g} / \mathrm{ml}$. $\beta-1,3$-Glucanase activity was about fourfold greater than chitinase activity in response to CHN1.5/20.

Phytoalexin accumulation in response to $\mathrm{CHN1.5/20}$ and copper sulfate. In order to optimize grapevine defense reactions and disease control with elicitor treatments, the highly active $\mathrm{CHN}, \mathrm{CHN} 1.5 / 20$, was used at $200 \mu \mathrm{g} / \mathrm{ml}$ in combination with low doses of $\mathrm{CuSO}_{4}$ ranging from 1 to $100 \mu \mathrm{g} / \mathrm{ml}$. As expected, CHN1.5/20 alone induced accumulation of phytoalexins in leaves, especially the trans isomeric forms (Fig. 5). When leaves were incubated with $\mathrm{CuSO}_{4}$ alone for $48 \mathrm{~h}$, the production of trans- and cis-resveratrol (Fig. 5A and B), trans- and cis- $\varepsilon$-vinferin (Fig. 5C and D), and trans- and cis-piceid (Fig. 5E and F) increased with increasing concentrations of $\mathrm{CuSO}_{4}$, reaching a maximal amount at $50 \mu \mathrm{g} / \mathrm{ml} \mathrm{CuSO}_{4}$ for trans isomers and from 5 to $50 \mu \mathrm{g} / \mathrm{ml}$ $\mathrm{CuSO}_{4}$ for the cis isomers. The trans isomers remained predominant and were more influenced by the $\mathrm{CuSO}_{4}$ concentration than the cis isomers. At a $\mathrm{CuSO}_{4}$ concentration of $100 \mu \mathrm{g} / \mathrm{ml}$, the amount of all forms of phytoalexins declined. The combination
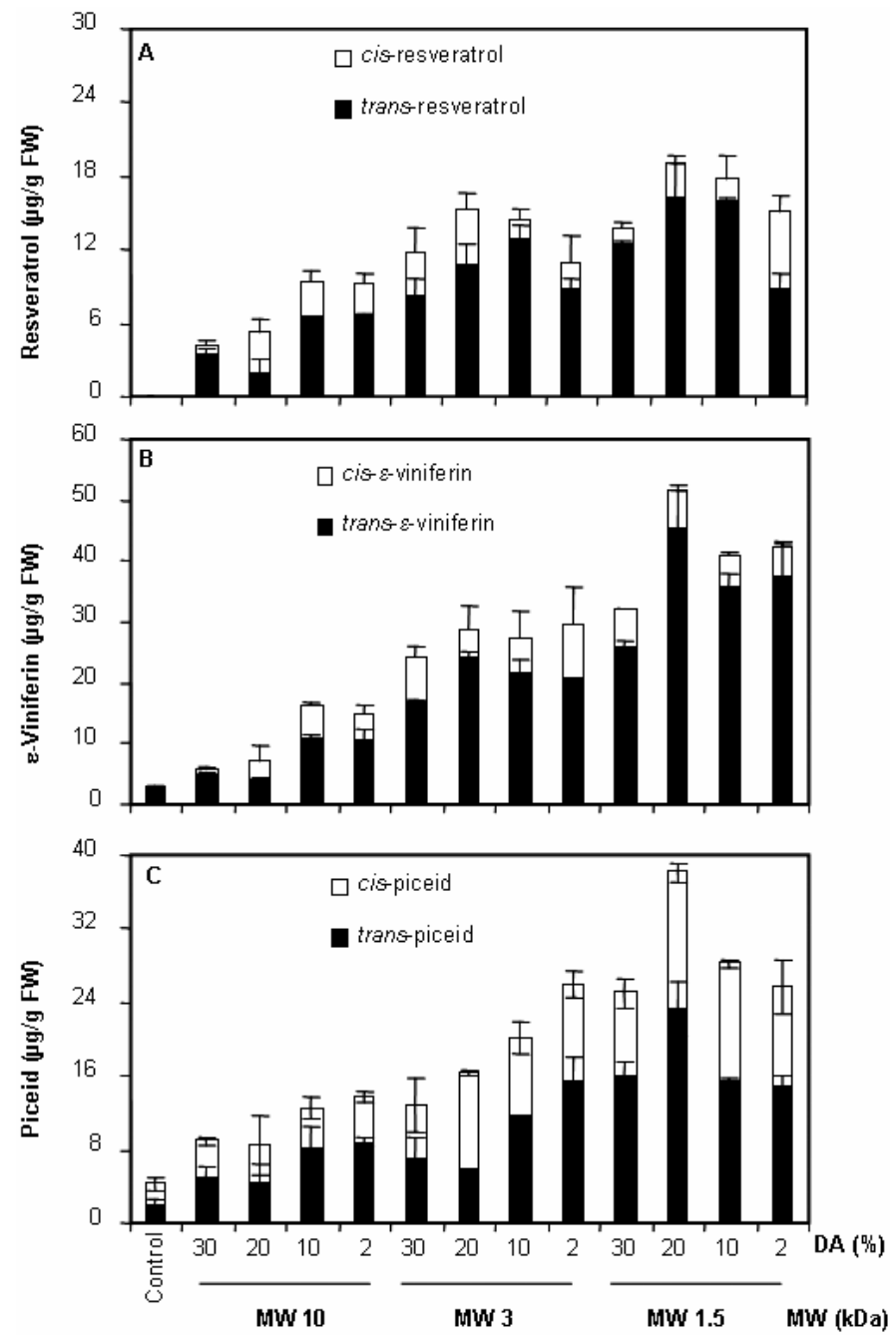

Fig. 2. Influence of the molecular weight and degree of acetylation on the activity of chitosan oligomers as elicitors of phytoalexins in grapevine leaves. Chitosan oligomers were applied at a final concentration of $200 \mu \mathrm{g} / \mathrm{ml}$ and leaves were harvested at $48 \mathrm{~h}$ for analysis of phytoalexins. Data are means \pm standard deviation from three independent experiments. Each bar represents the sum of trans- (solid part of the bar) and cis- (open part of the bar) phytoalexin. A, trans- and cis-resveratrol; B, trans- and cis-e-viniferin; and $\mathbf{C}$, trans- and cis-piceid. 
of both $\mathrm{CHN}$ and copper sulfate at concentrations $\leq 10 \mu \mathrm{g} / \mathrm{ml}$ was not significantly more effective than $\mathrm{CHN}$ alone for eliciting phytoalexins, but resulted in a strong accumulation of $c i s$-resveratrol and $c i s$ - $\varepsilon$-viniferin when copper concentration exceeded $10 \mu \mathrm{g} / \mathrm{ml}$.

Symptoms induced in grapevine leaves. Grapevine leaves incubated with $\mathrm{CHN}$ at concentrations $\leq 300 \mu \mathrm{g} / \mathrm{ml}$ did not develop any symptoms. However, treatment with $\mathrm{CuSO}_{4}$ alone at concentrations of 50 to $100 \mu \mathrm{g} / \mathrm{ml}$ resulted in small necrotic spots after 2 days. Incubation of leaves with both $\mathrm{CHN}$ and $\mathrm{CuSO}_{4}$ did not result in any disease symptom (data not shown).

Induction of resistance to $B$. cinerea and $P$. viticola. Because CHN1.5/20 induced different defense responses that reached their maximum within $48 \mathrm{~h}$, we tested whether $\mathrm{CHN}$ would induce resistance against pathogen infection. Grapevine leaves excised from plantlets were pre-incubated with different concentrations of $\mathrm{CHN}$, or buffer for $48 \mathrm{~h}$. Treated leaves were challenge-inoculated with the gray mold agent (B. cinerea). Figure 6 shows the diameter of lesions (symptoms) 6 days postinoculation. $\mathrm{CHN}$ induced significant protection against gray mold infection depending on its concentration. The average lesion diameter was reduced by about $50 \%$ in the $50 \mu \mathrm{g} / \mathrm{ml} \mathrm{CHN-treated} \mathrm{leaves} \mathrm{(Fig.} \mathrm{6A).} \mathrm{With}$ $\mathrm{CHN}$ at 100,200 , and $300 \mu \mathrm{g} / \mathrm{ml}$, this reduction level reached $60 \%$. In the presence of $\mathrm{CuSO}_{4}$, lesions were significantly smaller than those occurring in leaves treated with only CHN (Fig. 6B). Similar effects were observed when $\mathrm{CHN}$ and $\mathrm{CuSO}_{4}$ were sprayed on the leaves (data not shown). Treatment with CHN1.5/20 reduced the infection to a greater extent than treatment with CHN3/30 or CHN10/20 (data not shown). A similar degree of resistance was observed when $B$. cinerea was inoculated 4 days after CHN treatment (data not shown).

CHN-triggered resistance against $P$. viticola was measured in assays in which leaves from potted plants were sprayed on both

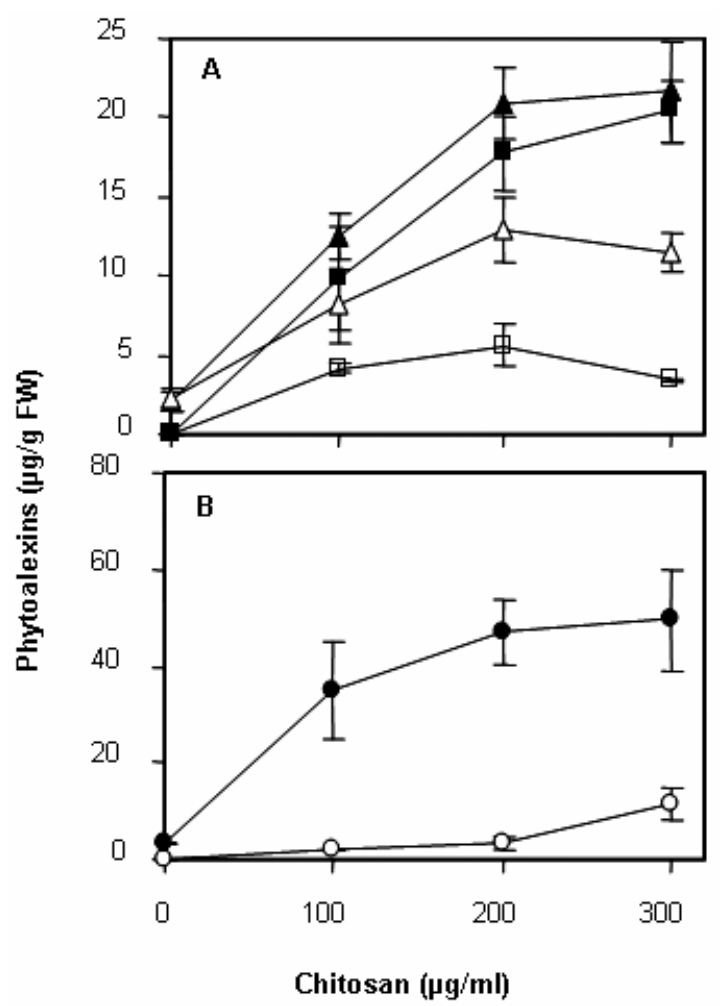

Fig. 3. Dose-dependent production of phytoalexins in grapevine leaves treated with chitosan of $1.5 \mathrm{kDa}$ and degree of acetylation of $20 \%$. Leaves were harvested at $48 \mathrm{~h}$ for analysis of phytoalexins. Data are means \pm standard deviation from three independent experiments. A, trans- (solid square) and cis-resveratrol (open square), trans- (solid triangle), and cis-piceid (open triangle); and $\mathbf{B}$, trans- (solid circle) and cis- $\varepsilon$-viniferin (open circle).
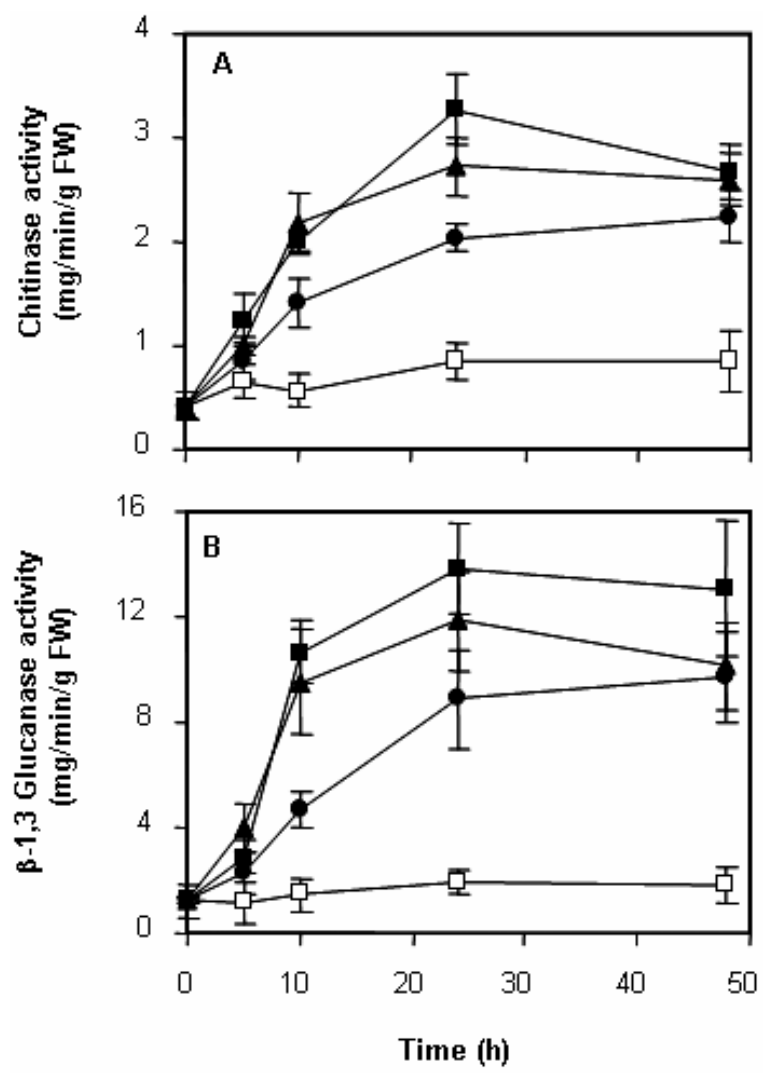

Fig. 4. Time-course and dose-response curves of $\mathbf{A}$, chitinase and $\mathbf{B}, \beta-1,3-$ glucanase activities in grapevine leaves treated with chitosan of $1.5 \mathrm{kDa}$ and degree of acetylation of $20 \%$. Data are means \pm standard deviation from three independent experiments. Control ( $0 \mu \mathrm{g} / \mathrm{ml}$, open square), $100 \mu \mathrm{g} / \mathrm{ml}$ (solid circle), $200 \mu \mathrm{g} / \mathrm{ml}$ (solid triangle), and $300 \mu \mathrm{g} / \mathrm{ml}$ (solid square).
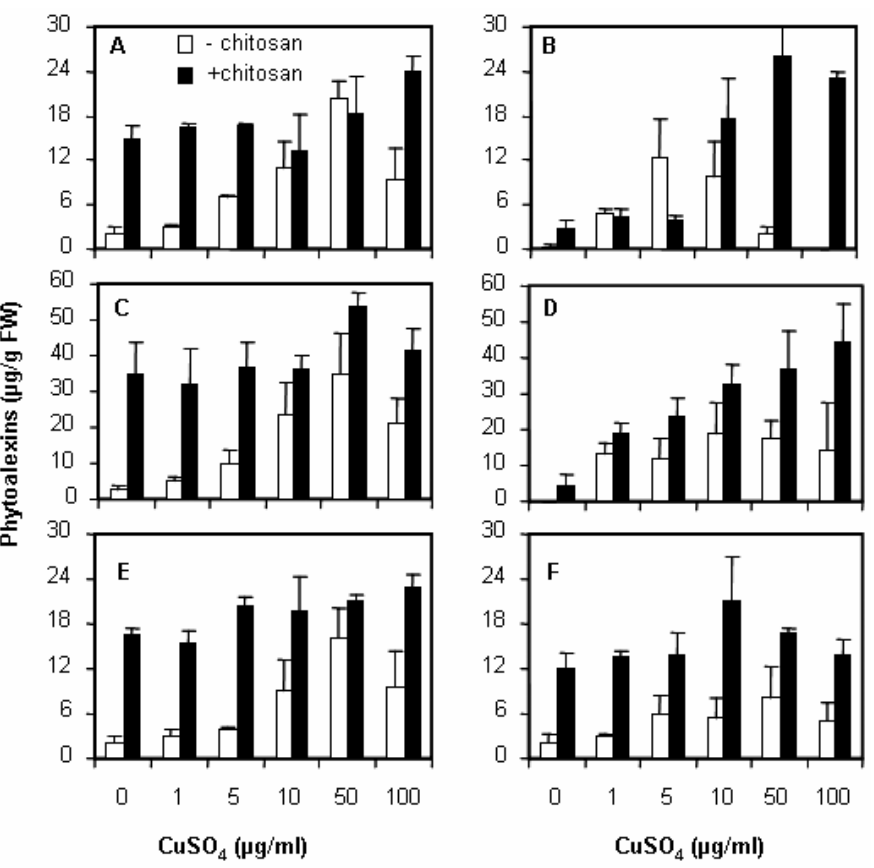

Fig. 5. Changes in the phytoalexin content of grapevine leaves treated with $\mathrm{CHN} 1.5 / 20$ and copper. Copper $\left(\mathrm{CuSO}_{4}\right)$ was applied at concentrations ranging from 0 to $100 \mu \mathrm{g} / \mathrm{ml}$ alone (open bars) or in the presence of CHN1.5/20 at $200 \mu \mathrm{g} / \mathrm{ml}$ (solid bars). Leaves were harvested at $48 \mathrm{~h}$ for analysis of phytoalexins. Data are means \pm standard deviation from three independent experiments. A, trans-resveratrol; B, cis-resveratrol; C, trans- $\varepsilon$-viniferin; D, cis- $\varepsilon$-viniferin; E, trans-piceid; and $\mathbf{F}$, cis-piceid. 
surfaces with $\mathrm{CHN}$ at $200 \mu \mathrm{g} / \mathrm{ml}$ with or without $\mathrm{CuSO}_{4}$ at $50 \mu \mathrm{g} / \mathrm{ml}$. After 8 days, the time needed for maximum induction of several defense reactions (data not shown), an aliquot of sporangial suspension was inoculated to the abaxial surface of leaves. Disease intensity was estimated 8 days postinoculation by measuring the leaf area covered by the oomycete. Results (Fig. 6C) indicate that $\mathrm{CHN}$ reduced the percentage of $P$. viticolainfected leaf surface from $42 \%$ in the control to $12 \%$ in the $\mathrm{CHN}$-sprayed leaves, corresponding to a $71 \%$ reduction in infection. Foliar sprays of a mixture of $\mathrm{CHN}$ at $200 \mu \mathrm{g} / \mathrm{ml}$ and $\mathrm{CuSO}_{4}$ at $50 \mu \mathrm{g} / \mathrm{ml}$ reduced pathogen growth by $85 \%$. $\mathrm{CuSO}_{4}$
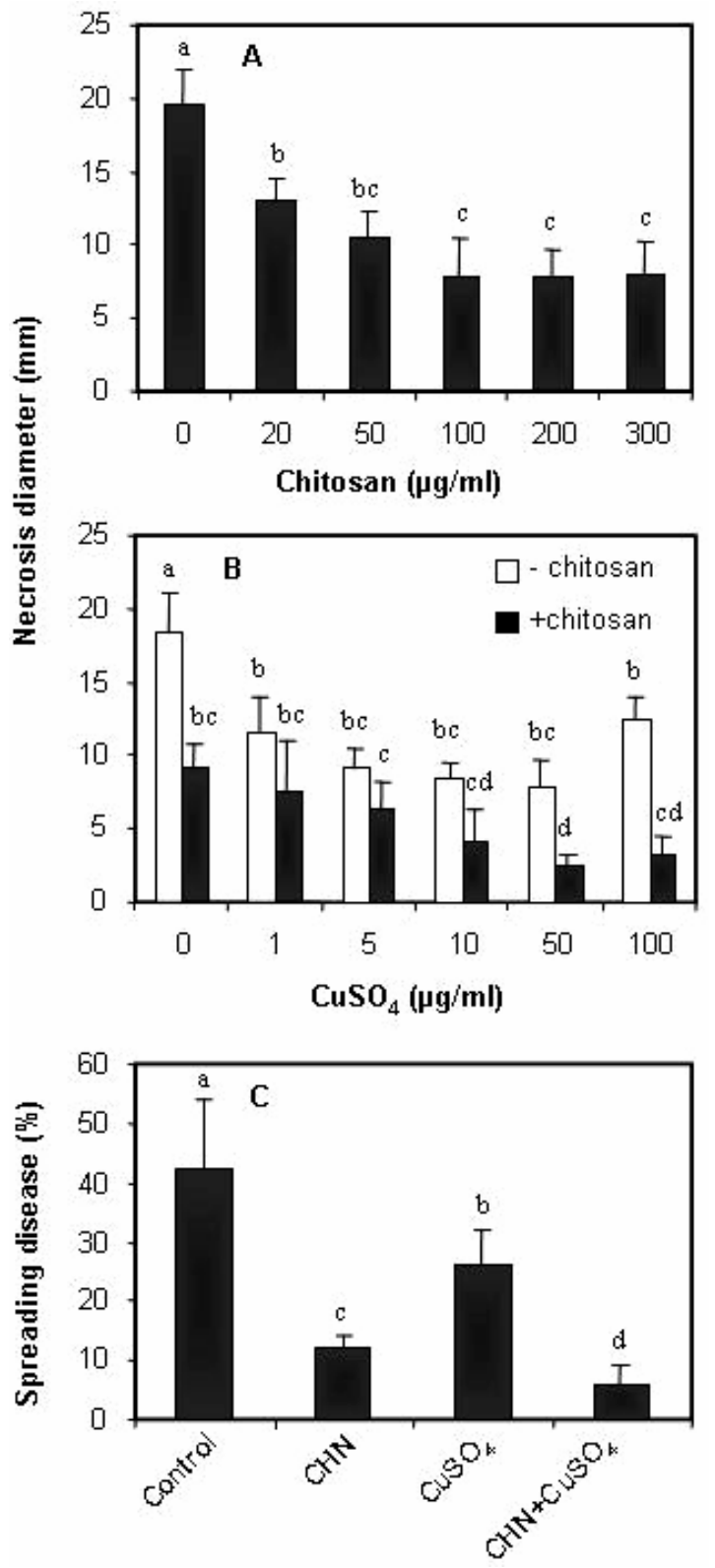

Fig. 6. Chitosan and copper sulfate-induced protection of grapevine leaves against Botrytis cinerea and Plasmopara viticola. A, Excised leaves were pretreated with CHN1.5/20 at concentrations ranging from 0 to $300 \mu \mathrm{g} / \mathrm{ml}$ for $48 \mathrm{~h}$ before challenge with $B$. cinerea. B, Excised leaves were pretreated with $\mathrm{CuSO}_{4}$ alone (open bars) at concentrations ranging from 0 to $100 \mu \mathrm{g} / \mathrm{ml}$ or together with CHN1.5/20 at $200 \mu \mathrm{g} / \mathrm{ml}$ (solid bars) for $48 \mathrm{~h}$ and then dropinoculated with $B$. cinerea. Data points are means \pm standard deviation of lesions formed 6 days postinoculation on 30 leaves. Values with the same letter are not significantly different $(P \leq 0.05)$. C, Development of downy mildew (Plasmopara viticola) on grapevine leaves sprayed with CHN1.5/20 at $200 \mu \mathrm{g} / \mathrm{ml}$ and $/ \mathrm{or} \mathrm{CuSO}_{4}$ at $50 \mu \mathrm{g} / \mathrm{ml}$. Data are means \pm standard deviation of infected leaf surface from 10 to12 different leaves per treatment. Values with the same letter are not significantly different $(P \leq 0.05)$. alone partially protected grapevine leaves against $P$. viticola by about $38 \%$.

Effects of $\mathrm{CHN}$ and $\mathrm{CuSO}_{4}$ on the pathogens. The direct effects of $\mathrm{CHN}$ with or without $\mathrm{CuSO}_{4}$ on $B$. cinerea and $P$. viticola were also investigated. The anti-Botrytis activity was determined by measuring the mycelium growth on potato dextrose agar medium (17) supplemented with $\mathrm{CHN}$ (50 to $300 \mu \mathrm{g} / \mathrm{ml}$ ) at $\mathrm{pH} 5.9$. After 5 days of incubation, CHN concentration below $200 \mu \mathrm{g} / \mathrm{ml}$ did not significantly inhibit $B$. cinerea growth. The highest CHN concentration caused only 10 to $15 \%$ inhibition of fungal growth. The combination of CHN at $200 \mu \mathrm{g} / \mathrm{ml}$ with $\mathrm{CuSO}_{4}$ at $50 \mu \mathrm{g} / \mathrm{ml}$ also resulted in a similar effect. This antifungal activity tended to decrease with time (data not shown). For $P$. viticola, the direct effect was assayed on fresh grapevine leaves sprayed with $\mathrm{CHN}$ at $200 \mu \mathrm{g} / \mathrm{ml}$ alone or together with $\mathrm{CuSO}_{4}$ at $50 \mu \mathrm{g} / \mathrm{ml}$ and immediately inoculated with sporangia. In both cases, pathogen growth was only slightly inhibited (by about 15 to $20 \%$ ).

\section{DISCUSSION}

CHN ( $\beta$-1-4 linked $N$-glucosamine) has been shown to induce defense responses in different plants $(15,25,27,51)$. The data reported here show that $\mathrm{CHN}$ oligomers also induce defense responses in grapevine leaves, as evidenced by an accumulation of stilbene phytoalexins, trans- and cis-resveratrol, $\varepsilon$-viniferins, and piceids, and a stimulation of chitinase and $\beta$-1,3-glucanase activities. Furthermore, the combination of $\mathrm{CHN}$ and $\mathrm{CuSO}_{4}$ increased phytoalexin production. This elicitor capacity of $\mathrm{CHN}$ and/or $\mathrm{CuSO}_{4}$ appeared to be associated with an induced protection of grapevine leaves against gray mold and downy mildew diseases.

Accumulation of trans-resveratrol, a reaction product of stilbene synthase, has been considered the primary inducible response of grapevine against a number of biotic and abiotic stresses $(17,33,43)$. The low amounts of cis-resveratrol recovered could result from a photoisomerization of its trans isomer, or from breakdown of the glucoside $c i s$-piceid. The production of $\varepsilon$ viniferin and piceid suggests that $\mathrm{CHN}$ can induce a rapid dimerization and glycosylation of resveratrol, respectively. Alternatively, $\varepsilon$-viniferin could also be produced through an oxidative coupling of resveratrol catalysed by a cell wall-localized peroxidase (14). These processes might be distinguished by comparing kinetics of accumulation of both trans-resveratrol and their metabolites in response to $\mathrm{CHN}$. The induction of resveratrol and $\varepsilon$-viniferin production by $\mathrm{CHN}$ is consistent with the induced PAL activity in grapevine leaves by CHN (49). Increasing the synthesis of stilbenes would be expected to enhance the plant's defense capacity. Most of these compounds have been shown to exhibit rather unspecific antimicrobial properties at physiological concentrations, enhancing the resistance of grapevine plants to $B$. cinerea, Plasmopara viticola, and Phomopsis viticola $(18,30,39,41)$.

The amount of all elicited phytoalexins was directly dependent upon MW and DA of CHN (Fig. 2). The trans isomers remained predominant and were more influenced by the $\mathrm{CHN}$ structure than cis isomeric forms. In all cases, $\mathrm{CHN}$ with a minimum chain length $(1.5 \mathrm{kDa})$ and a DA of $\leq 20 \%$ exhibited a high phytoalexininducing activity. The highly active CHN (CHN1.5/20) also induced chitinase and $\beta$-1,3-glucanase activities to a greater extent than laminarin (7) or oligogalacturonides (6). Both PR proteins are considered to be functionally implicated in the defense response directed toward chitin and $\beta$-glucans, which are major cell wall components of various fungi (50). These data corroborated some earlier findings showing that $\mathrm{CHN}$ oligomers ranging from 1.1 to $1.34 \mathrm{kDa}$ and $\mathrm{DA}$ of $<20 \%$ were more active than $\mathrm{CHN}$ of higher MW in inducing PAL activity in wheat (51) and phytoalexin production in rice leaves (53). Our results also underline the importance of the acetylation process for $\mathrm{CHN}$ biological activity. CHNs with lower DA had greater activity, suggesting that 
the chitin portion present in the CHN could be responsible for induced plant defense responses, through binding to a receptor on the plasma membrane (20). It has also been proposed that the activity of CHN with a low DA could be attributed to the charges along the chitin backbone resulting in the formation of multioligomer complexes with membrane components (35).

Treatments of $\mathrm{CuSO}_{4}$ alone or in combination with $\mathrm{CHN}$ induced accumulation of resveratrol and their metabolites in grapevine leaves. Interestingly, the induction of cis-resveratrol and cis$\varepsilon$-viniferin was very responsive to $\mathrm{CuSO}_{4}$, especially when its concentration exceeded $10 \mu \mathrm{g} / \mathrm{ml}$. To our knowledge, this is the first report showing that $\mathrm{CuSO}_{4}$ enhanced the elicitor-induced defense reactions in plants. Some of these results are in agreement with those of Rakwal et al. (44) and Adrian et al. (1) who showed that copper chloride and aluminium chloride elicited phytoalexin production in rice and grapevine leaves, respectively. The strong accumulation of cis-resveratrol and cis-e-viniferin could be explained by an enhanced release of cis-resveratrol from the glucoside cis-piceid. These compounds can be considered important markers for induced resistance of grapevine to the pathogens. The oxidative dimerization of resveratrol has been reported to be associated to resistance of grapevine cultivars to $P$. viticola, whereas its glycosylation is associated to sensitivity to this pathogen (42). In our system, $\mathrm{CuSO}_{4}$ alone (50 to $100 \mu \mathrm{g} / \mathrm{ml}$ ) provoked slight necroses in grapevine leaves after 2 days, while CHN (up to $300 \mu \mathrm{g} / \mathrm{ml}$ ) did not induce any symptom even in the presence of $\mathrm{CuSO}_{4}$ (data not shown). This indicates that unlike $\mathrm{CuSO}_{4}$, the $\mathrm{CHN}$-eliciting activity is not associated with cell death in grapevine leaves and that $\mathrm{CHN}$ can prevent possible $\mathrm{CuSO}_{4}$-induced cell death (37). CHN can act as a chelating agent that binds $\mathrm{CuSO}_{4}$. Moreover, one cannot exclude that sulfate groups might play a critical role in the $\mathrm{CuSO}_{4} / \mathrm{CHN}$-induced defense responses in grapevine. Recent reports $(36,38)$ have shown that sulfated oligosaccharides were more active than the unsulfated molecules in triggering various defense responses and systemic resistance against microbial pathogens.

The defense responses induced by CHN correlated with a reduction of B. cinerea and P. viticola infection (by about 60 and $70 \%$, respectively). The combination of $\mathrm{CHN}$ with copper sulfate enhanced both phytoalexin accumulation and protection against the pathogens. Several of these effects were checked and confirmed in leaves treated by floating or spraying them with $\mathrm{CHN}$ and $\mathrm{CuSO}_{4}$ (data not shown). The induced protection did not apparently result from any direct effect on pathogen growth but rather from greater induced plant resistance. Application of CHN1.5/20 at concentrations up to $300 \mu \mathrm{g} / \mathrm{ml}$ with or without $\mathrm{CuSO}_{4}(50 \mu \mathrm{g} / \mathrm{ml})$ to culture media or leaf surfaces just before inoculation only resulted in a slight growth inhibition of $B$. cinerea and $P$. viticola. These data are in agreement with other findings showing that increased resistance to $B$. cinerea and $P$. viticola was obtained in grapevine plants with high phytoalexin and PR protein levels $(12,13,17,42)$.

Taken together, our results demonstrate that $\mathrm{CHN}$ induces an accumulation of stilbene phytoalexins in grapevine leaves depending on its concentration, MW, and DA. The most active CHN oligomer also activated PR proteins in grapevine leaves. In addition, a combination of this $\mathrm{CHN}$ with low doses of $\mathrm{CuSO}_{4}$ resulted in a substantial accumulation of phytoalexins. This elicitor capacity of $\mathrm{CHN}$ and $\mathrm{CuSO}_{4}$ appeared to be associated with an induced protection against gray mold and downy mildew diseases, which resulted rather from greater induced plant resistance than from direct effect on the pathogens.

\section{ACKNOWLEDGMENTS}

Financial support was provided by Agrolor Society and Europôl'Agro. We thank A. Conreux, A. Collard, and A. Lemineur for their helpful technical assistance.

\section{LITERATURE CITED}

1. Adrian, M., Jeandet, P., Bessis, R., and Joubert, J. M. 1996. Induction of phytoalexin (resveratrol) synthesis in grapevine leaves treated with aluminum chloride $\left(\mathrm{AlCl}_{3}\right)$. J. Agric. Food Chem. 44:1979-1981.

2. Adrian, M., Jeandet, P., Veneau, J., Weston, L. A., and Bessis, R. 1997. Biological activity of resveratrol, a stilbenic compound from grapevines, against Botrytis cinerea, the causal agent for gray mold. J. Chem. Ecol. 23:1689-1702.

3. Agrawal, G. K., Rakwal, R., Tamogami, S., Yonekura, M., Kubo, A., and Saji, H. 2002. Chitosan activates defense/stress response(s) in the leaves of Oryza sativa seedlings. Plant Physiol. Biochem. 40:1061-1069.

4. Aït Barka, E., Eullaffroy, P., Clément, C., and Vernet, G. 2004. Chitosan improves development and protects Vitis vinifera L. against Botrytis cinerea. Plant Cell Rep. 22:608-614.

5. Alvarez, M. E., Pennell, R. I., Meijer, P. J., Ishikawa, A., Dixon, R. A., and Lamb, C. 1998. Reactive oxygen intermediates mediate a systemic signal network in the establishment of plant immunity. Cell 92:773-784.

6. Aziz, A., Heyraud, A., and Lambert, B. 2004. Oligogalacturonide signal transduction, induction of defence related responses and protection of grapevine against Botrytis cinerea. Planta 218:767-774.

7. Aziz, A., Poinssot, B., Daire, X., Adrian, M., Bézier, A., Lambert, B., Joubert, J. M., and Pugin, A. 2003. Laminarin elicits defence responses in grapevine and induces protection against Botrytis cinerea and Plasmopara viticola. Mol. Plant-Microbe Interact. 16:1118-1128.

8. Barber, M. S., Bertram, R. E., and Ride, J. P. 1989. Chitin oligosaccharides elicit lignification in wounded wheat leaves. Physiol. Mol. Plant Pathol. 34:3-12.

9. Benhamou, N. 1996. Elicitor-induced plant defence pathways. Trends Plant Sci. 1:233-240.

10. Bézier, A., Lambert, B., and Baillieul, F. 2002. Study of defense-related gene expression in grapevine leaves infected with Botrytis cinerea. Eur. J. Plant Pathol. 108:111-120.

11. Boller, T. 1995. Chemoperception of microbial signals in plant cells. Annu. Rev. Plant Physiol. Plant Mol. Biol. 46:189-214.

12. Bonomelli, A., Mercier, L., Franchel, J., Baillieul, F., Benizri, E., and Mauro, M. C. 2004. Response of grapevine defenses to UV-C exposure. Am. J. Enol. Vitic. 55:51-59.

13. Busam, G., Kassemeyer, H. H., and Matern, U. 1997. Differential expression of chitinases in Vitis vinifera L. responding to systemic acquired resistance activators or fungal challenge. Plant Physiol. 115:1029-1038.

14. Calderon, A., Zapata, J. M., and Barcelo, A. R. 1994. Peroxidasemediated formation of resveratrol oxidation products during the hypersensitive-like reaction of grapevine cells to an elicitor from Trichoderma viride. Physiol. Mol. Plant Pathol. 44:289-299.

15. Chang, M. M., Hadwiger, L. A., and Horovitz, D. 1992. Molecular characterization of a pea beta-1,3-glucanase induced by Fusarium solani and chitosan challenge. Plant Mol. Biol. 20:609-618.

16. Côté, F., and Hahn, M. G. 1994. Oligosaccharins: Structures and signal transduction. Plant Mol. Biol. 26:1379-1411.

17. Coutos-Thévenot, P., Poinssot, B., Bonomelli, A., Yean, H., Breda, C., Buffard, D., Esnault, R., Hain, R., and Boulay, M. 2001. In vitro tolerance to Botrytis cinerea of grapevine 41B rootstock in transgenic plants expressing the stilbene synthase Vst1 gene under the control of a pathogeninducible PR10 promoter. J. Exp. Bot. 358:901-910.

18. Dai, G. H., Andary, C., Mondolot-Cosson, L., and Boubals, D. 1995. Histochemical studies on the interaction between three species of grapevine, Vitis vinifera, V. rupestris and V. rotundifolia and the downy mildew fungus, Plasmopara viticola. Physiol. Mol. Plant Pathol. 46:177188.

19. Darvill, A. G., and Albersheim, P. 1984. Phytoalexins and their elicitors-a defense against microbial infection in plants. Annu. Rev. Plant Physiol. 35:243-275.

20. Day, R. B., Okada, M., Ito, Y., Tsukada, K., Zaghouani, H., Shibuya, N., and Stacey, G. 2001. Binding site for chitin oligosaccharides in the soybean plasma membrane. Plant Physiol. 126:1162-173.

21. Derckel, J. P., Audran, J. C., Haye, B., Lambert, B., and Legendre, L. 1998. Characterization, induction by wounding and salicylic acid, and activity against Botrytis cinerea of chitinases and $\beta$-1,3-glucanases of ripening grape berries. Physiol. Plant 104:56-64.

22. Doares, S. H., Syrovets, T., Weiler, E. W., and Ryan, C. A. 1995. Oligogalacturonides and chitosan activate plant defensive genes through the octadecanoid pathway. Proc. Natl. Acad. Sci. USA 92:4095-4098.

23. Domard, A., and Cartier, N. 1989. Glucosamine oligomers. 1. Preparation and characterization. Int. J. Biol. Macromol. 11:297-302.

24. Ebel, J., and Cosio, E. G. 1994. Elicitors of plant defense responses. Int. Rev. Cytol. 148:1-36.

25. Felix, G., Baureithel, K., and Boller, T. 1998. Desensitization of the perception system for chitosan fragments in tomato cells. Plant Physiol. 117:643-650. 
26. Hadwiger, L. A., and Beckman, J. M. 1980. Chitosan as a component of pea-Fusarium solani interactions. Plant Physiol. 66:205-211.

27. Hadwiger, L. A., Tomoya, O., and Hiroki, K. H. 1994. Chitosan polymer sizes effective in inducing phytoalexin accumulation and fungal suppression are verified with synthesized oligomers. Mol. Plant-Microbe Interact. 7:531-533.

28. Hamiduzzaman, M. M., Jakab, G., Barnavon, L., Neuhaus, J. M., and Mauch-Mani, B. 2005. $\beta$-Aminobutyric acid-induced resistance against downy mildew in grapevine acts through the potentiation of callose formation and jasmonic acid signalling. Mol. Plant-Microbe Interact. 18:819-829.

29. Hammerschmidt, R. 1999. Phytoalexins: What have we learned after 60 years? Annu. Rev. Phytopathol. 37:285-306.

30. Hoos, G., and Blaich, R. J. 1990. Influence of resveratrol on germination of conidia and mycelial growth of Botrytis cinerea and Phomopsis viticola. J. Phytopathol. 129:102-110

31. Inui, H., Yamaguchi, Y., and Hirano, S. 1997. Elicitor actions of $N$ acetylchitooligosaccharides and laminarioligosaccharides for chitinase and L-phenylalanine ammonia-lyase induction in rice suspension culture. Biosci. Biotechnol. Biochem. 61:975-978.

32. Jeandet, P., Breuil, A. C., Adrian, M., Weston, L. A., Debord, S., Meunier, P., Maume, G., and Bessis, R. 1997. HPLC analysis of grapevine phytoalexins coupling photodiode array detection and fluorimetry. Anal. Chem. 69:5172-5177.

33. Jeandet, P., Douillet-Breuil, A. C., Bessis, R., Debord, S., Spaghi, M., and Adrian, M. 2002. Phytoalexins from the Vitaceae: Biosynthesis, phytoalexin gene expression in transgenic plants, antifungal activity, and metabolism. J. Agric. Food Chem. 50:2731-2741.

34. Jones, D. A., and Takemoto, D. 2004. Plant innate immunity-direct and indirect recognition of general and specific pathogen-associated molecules. Curr. Opin. Immunol. 16:48-62.

35. Kauss, H., Jeblick, W., and Domard, A. 1989. The degrees of polymerization and $\mathrm{N}$-acetylation of chitosan determine its ability to elicit callose formation in suspension cells and protoplasts of Catharanthus roseus. Planta 178:385-392.

36. Klarzynski, O., Descamps, V., Plesse, B., Yvin, J. C., Kloareg, B., and Fritig, B. 2003. Sulfated fucan oligosaccharides elicit defense responses in tobacco and local and systemic resistance against tobacco mosaic virus. Mol. Plant-Microbe Interact. 16:115-122.

37. Loeffler, C., Berger, S., Guy, A., Durand, T., Bringmann, G., Dreyer, M., von Rad, U., Durner, J., and Mueller, M. J. 2005. B -Phytoprostanes $^{-}$ trigger plant defense and detoxification responses. Plant Physiol. 137: 328-340.

38. Ménard, R., Alban, S., De Ruffray, P., Jamois, F., Franz, G., Fritig, B., Yvin, J. C., and Kauffman, S. 2004. $\beta-1,3-$ Glucan sulfate, but not $\beta-1,3$ glucan, induces the salicylic acid signaling pathway in tobacco and Arabidopsis. Plant Cell 16:3020-3032.
39. Montero, C., Cristescu, S. M., Jiménez, J. B., Orea, J. M., te Lintel H. S. Harren, F. J. M., and González, U. A. 2003. trans-Resveratrol and grape disease resistance. A dynamical study by high-resolution laser-based techniques. Plant Physiol. 131:129-138.

40. Murashige, T., and Skoog, A. 1962. A revised medium for rapid growth and bioassays with tobacco tissue cultures. Physiol. Plant 15:473-497.

41. Pezet, R., Gindro, K., Viret, O., and Richter, H. 2004. Effects of resveratrol, viniferins and pterostilbene on Plasmopara viticola zoospore mobility and disease development. Vitis 43:145-148.

42. Pezet, R., Gindro, K., Viret, O., and Spring, J. L. 2004. Glycosylation and oxidative dimerzation of resveratrol are respectively associated to sensitivity and resistance of grapevine cultivars to downy mildew. Physiol. Mol. Plant Pathol. 65:297-303.

43. Pezet, R., Perret, C., Jean-Denis, J. B., Tabacchi, R., Gindro, K., and Viret, O. 2003. $\varepsilon$-Viniferin, a resveratrol dehydrodimer: One of the major stilbenes synthesized by stressed grapevine leaves. J. Agric. Food Chem. 51:5488-5492.

44. Rakwal, R., Tamogami, S., and Kodama, O. 1996. Role of jasmonic acid as a signaling molecule in copper chloride-elicited rice phytoalexin production. Biosci. Biotechnol. Biochem. 60:1046-1048.

45. Roby, D., Gadelle, A., and Toppan, A. 1987. Chitin oligosaccharides as elicitors of chitinase activity in melon plants. Biochem. Biophys. Res. Commun. 143:885-892.

46. Somssich, I., and Hahlbrock, K. 1998. Pathogen defense in plants-A paradigm of biological complexity. Trends Plant Sci. 3:86-90.

47. Tang, M., and Smith, J. C. 2001. Elicitor induced defence response in Medicago sativa. New Phytol. 149:401-418.

48. Tassoni, A., Fornalè, S., Franceschetti, M., Musiani, F., Michael, A. J., Perry, B., and Bagni, N. 2005. Jasmonates and Na-orthovanadate promote resveratrol production in Vitis vinifera cv. Barbera cell cultures. New Phytol. 166:895-905.

49. Trotel-Aziz, P., Couderchet, M., Vernet, G., and Aziz, A. 2006. Chitosan stimulates defense reactions in grapevine leaves and inhibits development of Botrytis cinerea. Eur. J. Plant Pathol. 114:405-413.

50. Van Loon, L. C., and Van Strien, E. A. 1999. The families of pathogenesis-related proteins, their activities, and comparative analysis of PR-1 type proteins. Physiol. Mol. Plant Pathol. 3:85-97.

51. Vander, P., Varum, K. M., Domard, A., El-Gueddari, N. E., and Moerschbacher, B. M. 1998. Comparison of the ability of partially $N$ acetylated chitosans and chitooligosaccharides to elicit resistance reactions in wheat leaves. Plant Physiol. 118:1353-1359.

52. Wirth, S. J., and Wolf, G. A. 1992. Microplate colorimetric assay for endo-acting cellulase, xylanase, chitinase, $\beta$-1,3-glucanase and amylase extracted from forest soil horizons. Soil Biol. Biochem. 24:511-519.

53. Yamada, A., Shihuya, N., Kodama, O., and Akatsuka, T. 1993. Induction of phytoalexin formation in suspension cultured rice cells by $\mathrm{N}$-acetylchitooligosaccharide. Biosci. Biotechnol. Biochem. 57:405-409. 